\title{
Finite Control Set Model Predictive Control for Grid- Tied Quasi-Z-Source based Multilevel Inverter
}

\author{
Mohamed Trabelsi ${ }^{1}$, Sertac Bayhan ${ }^{1,2}$, Haitham Abu-Rub ${ }^{1,3}$, Lazhar Ben-Brahim ${ }^{4}$, Pericle Zanchetta ${ }^{5}$ \\ ${ }^{1}$ Department of Electrical and Computer Engineering, Texas A\&M University at Qatar, Qatar Foundation, Doha, \\ Qatar \\ ${ }^{2}$ Department of Electronics and Automation, Gazi University, Ankara, Turkey \\ ${ }^{3}$ Qatar Environment and Energy Research Institute (QEERI), HBKU, Qatar Foundation, Doha, Qatar \\ ${ }^{4}$ Electrical Engineering Department, Qatar University, Doha, QATAR \\ ${ }^{5}$ Department of Electrical and Electronic Engineering, University of Nottingham, United Kingdom \\ mohamed.trabelsi@qatar.tamu.edu
}

\begin{abstract}
In this paper, a finite control set Model Predictive Control (MPC) for grid-tie quasi-Z-Source (qZS) based multilevel inverter is proposed. The proposed Power Conditioning System (PCS) consists of a single-phase 2-cell Cascaded H-Bridge (CHB) inverter where each module is fed by a qZS network. The aim of the proposed control technique is to achieve grid-tie current injection, low Total Harmonic Distortion (THD) current, unity power factor, while balancing DC-link voltage for all qZS-CHB inverter modules. The feasibility of this strategy is validated by simulation using Matlab/Simulink environment.
\end{abstract}

Keywords-quasi-Z-Source Network; Power Conditioning System; Multilevel Inverter; Grid Integration.

\section{INTRODUCTION}

Power converters have become over the last decades an enabling technology for a wide range of renewable energy (RE) applications mainly due to their higher efficiency and performance in exploiting the energy from the sources. For instance in photovoltaic (PV) power generation systems, power converters are able to meet the increasing demand of load (extracting the maximum power), and injecting electric current to the grid with unity power factor. The rich diversity of applications require power electronic converters that have different power ratings operating at different voltage/current levels, and even having different types of dc input sources (current or voltage). Therefore, wide range of Multilevel Inverter (MLI) topologies have been developed over the years, particularly in the last decade to cater the needs and fulfill the specifications of each niche. MLIs can handle high volt/current by means of advanced medium-power semiconductor technology [1-2]. Several surveys have introduced these topologies $[1,3]$. Indeed, using the same switching frequency, the output waveforms can be improved comparing with the classical two-level inverter topologies. Among the well-known MLI topologies, cascaded H-bridge (CHB) inverters are characterized by their reduction of filtering elements, high modularity, high flexibility in the multilevel voltage synthesis, high fault tolerance, and high reliability (presence of redundant states which gives flexibility in selecting switching control approaches for optimized output performance) [4-5]. Nevertheless, like any other inverter topology, the H-bridge module misses the boost feature. Thus, the integration of DCDC boost converter between the DC source and the H-Bridge inverter is vital to get the required boosted $\mathrm{AC}$ voltage. This additional boost converter increases the cost, weight, size, control complexity, and lowers in turn the system efficiency and reliability. In addition, to have safe operation of the inverter (avoid short-circuit), a dead-time should always be introduced, which results in distortion of the output voltage waveform (cyclical fluctuations).

Recently, a qZS inverter topology has been developed (improvement of the Z-source topology characterized by lower component ratings and continuous DC source current) for connecting PV modules to the load/grid. This is a single-stage power converter topology that employs a capacitor-inductor network and has voltage-boost and voltage-buck capabilities [68]. The qZS-network utilizes shoot-though states to boost the input voltage and regulate the DC link voltage for the inverter. The peak DC link voltage appears across the load terminals during the active states of the inverter. Then, the DC link voltage is pulsating in nature between zero and peak DC link voltage. Moreover, a qZS-CHB topology for grid-tie PV systems was proposed in [9-14]. This mix-topology is characterized by highquality staircase output voltage with lower harmonic distortions, independent DC-link voltage compensation with a special voltage step-up/down function in a single-stage power conversion, and independent control of power delivery with high reliability [13]. Moreover, this inverter solves the imbalance problem of DC-link voltage in traditional CHB inverters. It is worth noting that the accurate control of the DC-link peak voltage is very critical for the regulation of the amount of the total power delivered to the grid.

Usually, PID controllers used in conjunction with a modulation technique are the main solution for power electronic converters regulation. However many other advanced control methods have been developed in the past decades. Among them, MPC is one of the most promising control technique, because it combines in a very simple form the discrete nature of the 
controller with the discrete nature of the power converter. MPC has been studied for nearly three decades [15] and is considered as one of the most advanced control theories available nowadays [16-23]. The development and application of Model-based Predictive Control was initially slowed down due to its high computational cost. However, in the last two decades, powerful digital control platforms have been developed, e.g., FieldProgrammable Gate Arrays (FPGAs) and Digital-SignalProcessors (DSPs) have become the conventional solution for control of electrical and electronics engineering systems [2425]. MPC is characterized by its capability to be used in a variety of processes and application and by its simplicity for advanced engineering systems with high number of dynamics, where hardconstraints, soft-constraints and non-linearities can be included easily into the control law. Conventional MPC is currently used in a wide range of fields from vehicle applications, thermal management [15], electrical drives to grid interfacing of renewable energies [26-31]. Moreover, MPC is considered as a real and effective solution to traditional controllers based on linear control theory and Pulse-Width-Modulation (PWM) [3233]. Note that, [33] is the state-of-the-art in electrical systems based on power electronic converters where interchange of energy between different power sources is performed.

This paper first explains the principle of operation and mathematical modelling of the grid connected qZS-CHB topology. A finite set control MPC approach of the proposed system is then presented and discussed. The MPC structure is capable of generating unity power factor, while low THD current is delivered to the grid. Besides, the amount of total power delivered to the grid is regulated through a DC-link peak voltage control employed in every qZS-CHB module to balance the DC-link voltages (by controlling the shoot-through ratio). Simulations of the proposed system are conducted using Matlab/Simulink to validate the MPC technique. Simulation approach is applicable even for qZS-CHB inverters with a large number of cells.

\section{THEORETICAL BACKGROUND}

\section{A. $q Z S-C H B$ topology}

The proposed single-phase qZS based PCS is illustrated in Fig. 1. The shown system consists of two grid-tie CHB inverters through filtering inductors, where each cell is connected to a qZS network. This network consists of two inductors, two capacitors and one diode. This switchless topology is used to interface the PV output voltage with the inverter input while having a boost capability.

The output voltage of the qZS-CHB inverter is multilevel type (5-level output voltage) resulting from the sum of the two module output voltages. This number of levels $L$ is given by:

$$
L=2 n+1
$$

with $n$ is the number of cells.

\section{B. Mathematical modeling}

The qZS converter's operation modes can be alienated into two states; non-shoot-through and shoot-through states. During the non-shoot-through state, the inverter is controlled as a conventional $\mathrm{H}$-Bridge inverter and the derivations of the state variables $i_{L i 1}$, and $V_{c i 1}$ for each cell ( $\mathrm{i}$ is the cell number) are obtained by (2) and (3).

$$
\begin{gathered}
C \frac{d V_{C i 1}}{d t}=i_{L i 1}(t)-i_{g}(t) \\
L \frac{d i_{L i 1}}{d t}=V_{i n}-V_{C i 1}(t)
\end{gathered}
$$

In the shoot-through state, both switches in a same leg are turned on simultaneously. The system equations for this state are given by (4) and (5). The above-mentioned configurations as well as the different current and voltage polarities are illustrated in Fig. 2.

$$
\begin{gathered}
C \frac{d V_{C i 1}(t)}{d t}=-i_{L i 2}(t) \\
L \frac{d i_{L i 2}(t)}{d t}=V_{C i 1}(t)
\end{gathered}
$$

In addition, according to Fig. 1, the output voltage $V_{\text {out }}$ in terms of its current and filter parameters is given by:

$$
V_{\text {out }}(t)=L_{f} \frac{d i_{g}(t)}{d t}+r_{f} i_{g}(t)+V_{\text {grid }}(t)
$$

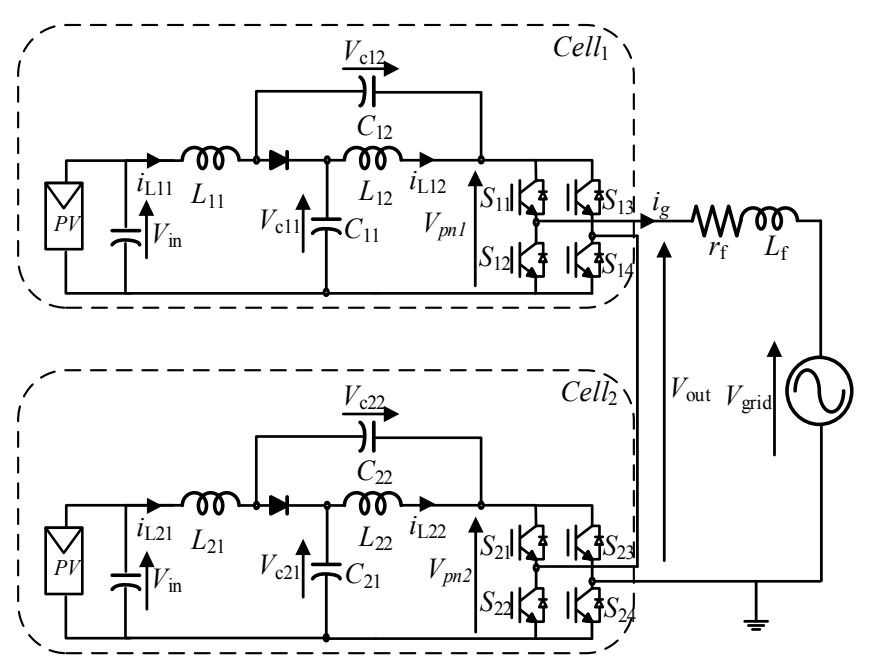

Fig. 1. Proposed 2-cell grid-connected power conditioning system

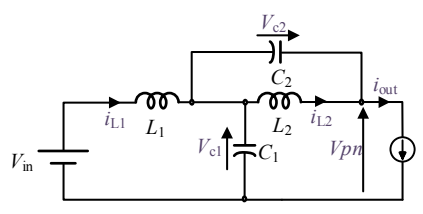

(a)

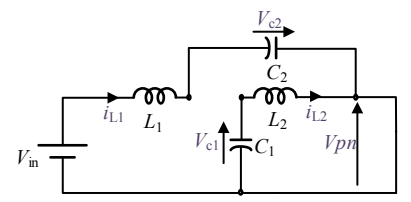

(b)

Fig. 2. The operation modes of the qZS converter; (a) Non-shoot-through state, (b) shoot-through state 
Considering $T_{s w}$ as one switching cycle, $T_{0}$ as the interval of the shoot-through mode, and $T_{1}$ as the interval of non-shootthrough mode, their relationship is given by $T_{0}+T_{1}=T_{S w}$ and the shoot-through duty ratio is calculated by $D=T_{0} / T_{s w}$. Then, the capacitor voltages as well as the peak value (denoted by “^”) of the DC-link voltage $V_{p n}$ can be obtained in steady state as given by (7).

$$
\left\{\begin{array}{c}
V_{C i 1}=\frac{1-D}{1-2 D} V_{i n} \\
V_{C i 2}=\frac{D}{1-2 D} V_{i n} \\
\hat{V}_{p n}=V_{C i 1}+V_{C i 2}=\frac{1}{1-2 D} V_{i n}=B V_{i n}
\end{array}\right.
$$

where $B$ is the boosting factor.

In order to generate the different voltage levels for the proposed topology, at non-shoot-through states, it is essential to control the switching variable $S_{i j}$ ( $i$ is the cell number and $\mathrm{j}$ is the switch number) in line with the following expression:

$$
V_{\text {out }}=V_{\text {pni }} \sum_{i=1}^{n}\left(S_{i 1}-S_{i 3}\right)
$$

Including all voltage level redundancies, the total number of switching signal combinations is given by:

$$
C_{S}=2^{2 n}=16
$$

Moreover, during the shoot-through states, three additional switching states can be noted. These switching combinations result from turning on at the same time both switches on the same leg for one of the cells or for both. Then, the total number of switching signal combination $C_{s}$ becomes 19 .

\section{Model Predictive Control Strategy}

The control objectives of the qZS-CHB based grid-tie PCS are the DC-link peak voltage regulation for all qZS-CHB modules, input current regulation in continuous mode, and power injection to the grid with unity power factor and low harmonic distortion. The overall control scheme shown in Fig. 3 is proposed to fulfill these purposes.

The shown scheme consists of three main stages, which are: 1) Generation of state variable references; 2) Model prediction; and 3) Cost function optimization.

\section{1) Generation of references}

As shown in Fig. 3, the phase-locked loop (PLL) senses the phase angle of the grid voltage to ensure the grid synchronization with unity power factor (the grid current is in phase with the grid voltage). Then a sine generator is used to generate the reference grid current. The reference inductor currents $i_{L 1}{ }^{*}$ are calculated by dividing the system power rating $P$ over the input voltage $V_{\text {in }}(10)$. The capacitor voltage references $V_{c l}{ }^{*}$ are also given by (4).

$$
\left\{\begin{array}{c}
i_{L i 1}{ }^{*}=\frac{P}{2 V_{\text {in }}} \\
V_{c i 1}{ }^{*}=V_{\text {in }} \frac{1-D}{1-2 D}
\end{array}\right.
$$

\section{2) Model prediction}

The main idea of the MPC scheme implemented in this paper is the prediction of the of the grid current $i_{g}{ }^{k+1}$, qZS inductor currents $i_{L i 1}{ }^{k+1}$, and qZS capacitor voltages $V_{c i 1}{ }^{k+1}$ for each possible switching state (voltage vector generated by the inverter) by the means of discrete equations of the system state variables.

To do so, using the forward Euler approximation (11) for the derivations (2)-(6) with a sampling time $T_{s}$, the prediction of the state variables at the $(k+1)$ sample in terms of the measurements at the previous $(k)$ sample can be expressed by (12)-(14).

$$
\begin{gathered}
\frac{d f(t)}{d t}=\frac{f^{k+1}-f^{k}}{T_{s}} \\
V_{c i 1}{ }^{k+1}=V_{c i 1}{ }^{k}+\frac{T_{s}}{C_{i 1}}\left(i_{L i 1}{ }^{k}-i_{g}{ }^{k}\right) \\
i_{L i 1}{ }^{k+1}=i_{\text {Li1 }}{ }^{k}+\frac{T_{s}}{L_{i 1}}\left(V_{\text {out }}{ }^{k}-V_{c i 1}{ }^{k}\right) \\
i_{g}{ }^{k+1}=\left(1-\frac{r_{f}}{L_{f}} T_{s}\right) i_{g}{ }^{k}+\frac{T_{s}}{L_{f}}\left(V_{\text {out }}{ }^{k}-V_{\text {grid }}{ }^{k}\right)
\end{gathered}
$$

\section{3) Cost function}

The proposed cost function has two objectives: minimize the error between the predicted grid current $i_{g}{ }^{k+1}$, inductor currents $i_{L i 1}{ }^{k+1}$, and capacitor voltages $V_{c i 1}{ }^{k+1}$ and their references, and balance in turn the DC-link capacitor voltages. These control objectives are represented as follows:

$$
g=\lambda_{i g}\left|i_{g}^{*}-i_{g}{ }^{k+1}\right|+\sum_{i=1}^{2} \lambda_{V c}\left|V_{c 1}{ }^{*}-V_{c i 1}{ }^{k+1}\right|+\lambda_{i L}\left|i_{L 1}{ }^{*}-i_{L i 1}{ }^{k+1}\right|
$$

where $\lambda_{i g}, \lambda_{V c}$, and $\lambda_{i L}$ are weighting factors, which can be adjusted according to the desired performance (the tuning of the weighting factors is done by trial and error strategy). The switching state that minimizes the cost function is chosen and then applied at the next sampling instant. 


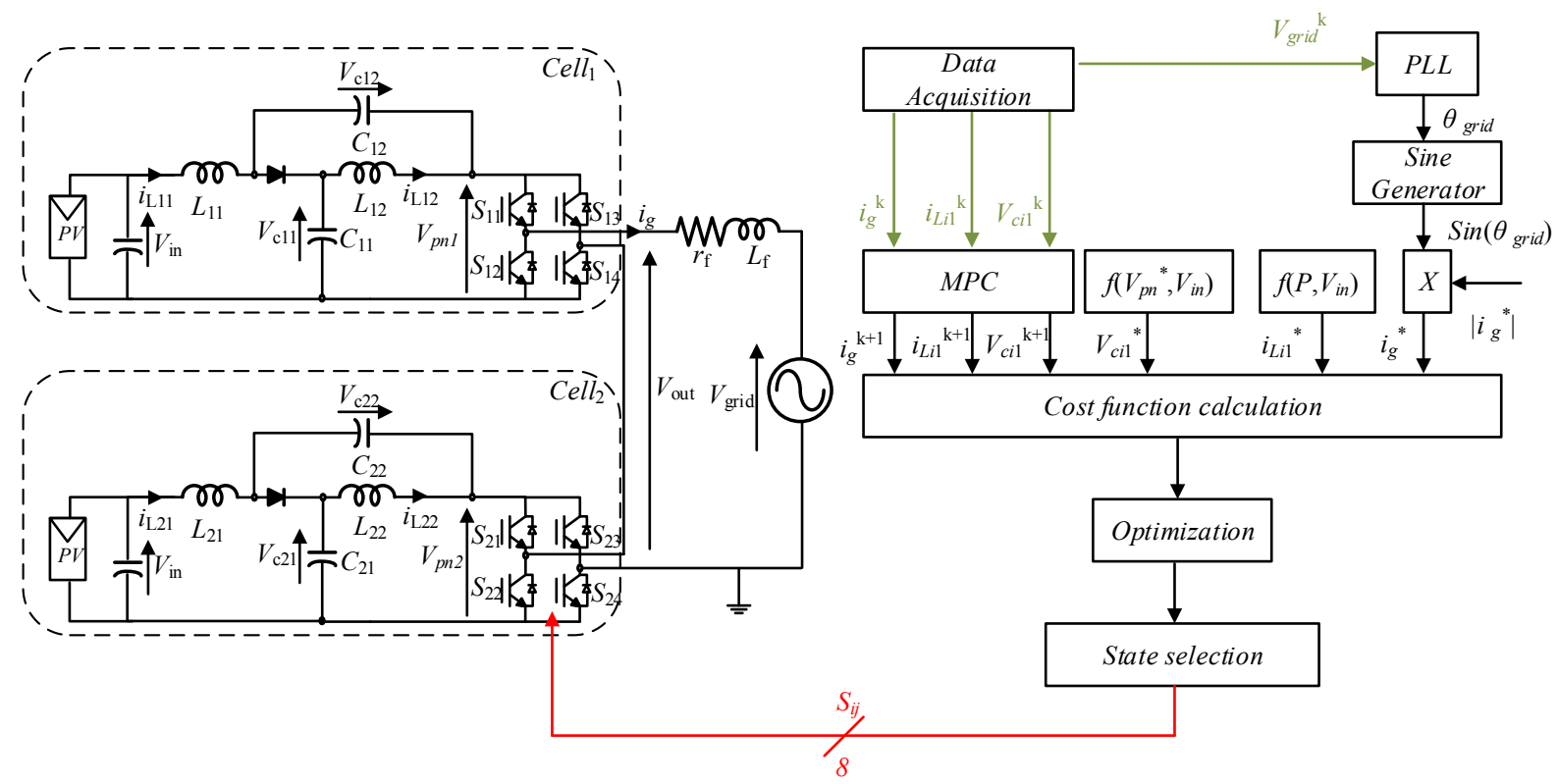

Fig. 3. Proposed Control Strategy

\section{SimUlation RESUlTS}

In order to validate the proposed concept, simulations were performed using MATLAB/SIMULINK ${ }^{\circledR}$ and results are presented to show the effectiveness of the proposed method in achieving grid-tie current injection, low current THD, and balancing the DC-link voltage for both qZS-CHB inverter modules. The system parameters are reported in Table I.

In the studied case, the peak value of the qZS-CHB reference grid current is set to 7A and the DC-link voltage reference $v_{p n}{ }^{*}$ is fixed at $240 \mathrm{~V}$ ( $B=1.6$, with $\mathrm{B}$ is the boosting factor). Thus, for the boost conversion mode, the qZS network is boosting the input voltage $V_{i n}(150 \mathrm{~V})$ to the required reference value $v_{p n}{ }^{*}$ by varying the shoot through value $D$. Fig. 4 shows the simulation results of the regulated DC-link voltage and capacitor voltages. It can be noted that the DC-link voltage is properly regulated around the reference value $(240 \mathrm{~V}), V_{c 1}$ and $V_{c 2}$ are controlled around the reference values $\left(V_{c l}{ }^{*}=195 \mathrm{~V}, V_{c 2}{ }^{*}=45 \mathrm{~V}\right)$ given by (10).

Fig. 5 shows that the qZS inductor current is maintained in the continuous mode allowing reducing the input stress. In addition, Fig. 6 denotes a zoom of Fig. 4 and Fig. 5 presenting the evolution of the qZS variables with the shoot-through state. The lower part of the figure shows that the DC-link voltage is properly regulated around the reference value $(240 \mathrm{~V})$ while the upper part shows that the qZS inductor current is increasing during the shoot-through, decreasing during the non-shootthrough state, and always maintained in the continuous mode. In Fig. 7, the grid current is plotted against its reference showing an excellent tracking quality. The current THD is given in Fig. 8. The 5-level output voltage is shown in Fig. 9. Finally, Fig. 10 shows the measured total output power as well as the grid current and the qZS inductor current during a step change of the active power reference.
TABLE I. SIMUlation PARAMETERS

\begin{tabular}{lc}
\hline \hline \multicolumn{1}{c}{ Parameters } & Value \\
\hline Total output power $\left(\mathrm{P}_{\text {total }}\right)$ & $1.2 \mathrm{~kW}$ \\
AC grid RMS voltage $\left(\mathrm{V}_{\text {grid }}\right)$ & $240 \mathrm{~V}$ \\
qZS inductances $\left(\mathrm{L}_{1}, \mathrm{~L}_{2}\right)$ & $2.5 \mathrm{mH}$ \\
qZS capacitances $\left(\mathrm{C}_{1}, \mathrm{C}_{2}\right)$ & $4.7 \mathrm{mF}$ \\
$\begin{array}{l}\text { Filtering inductance }(\mathrm{L}) \\
\text { PV array voltage for qZS-HBI } \\
\text { module }\left(\mathrm{V}_{\text {in }}\right)\end{array}$ & $150 \mathrm{mH}$ \\
AC load frequency $(\mathrm{f})$ & $50 \mathrm{~Hz}$ \\
\hline \hline
\end{tabular}

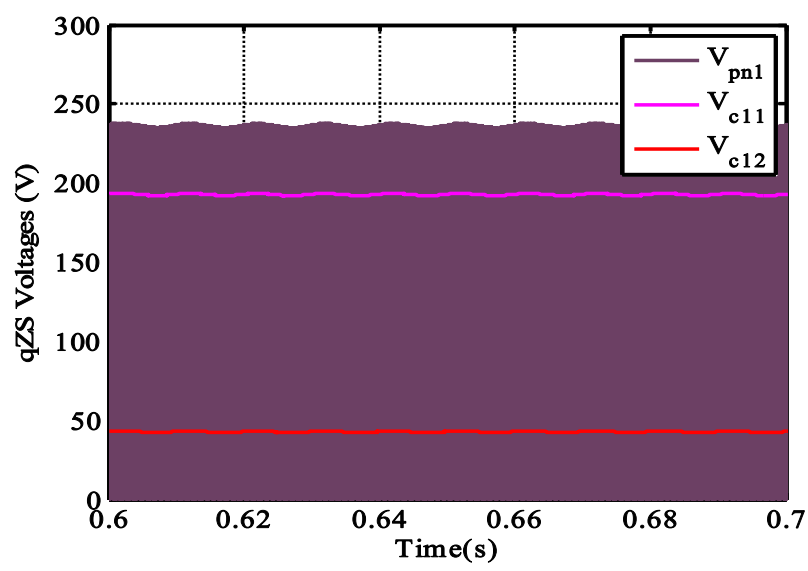

Fig. 4. qZS DC-Link voltage 


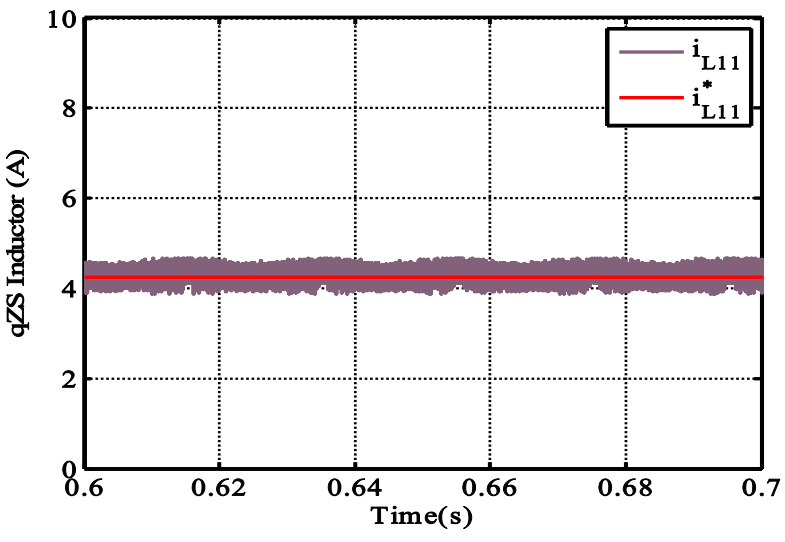

Fig. 5. qZS inductor current
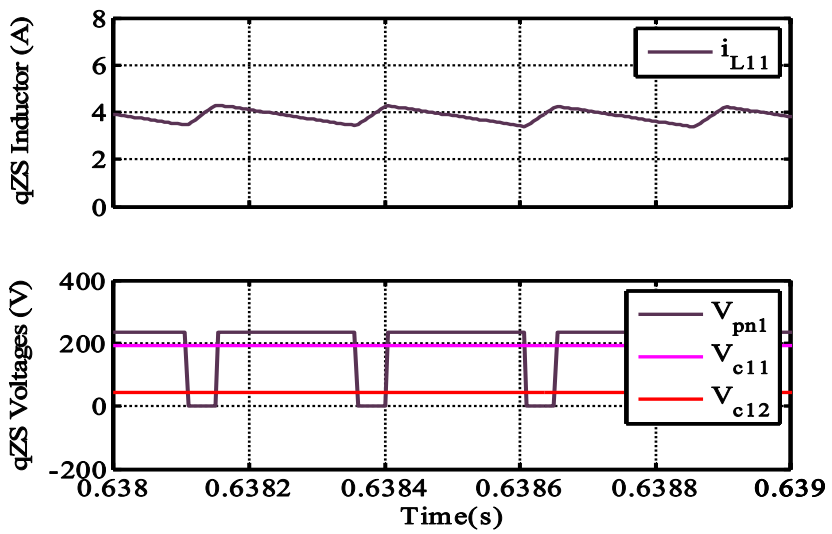

Fig. 6. Zoomed snapshot of the qZS inductor current and DC-link voltage

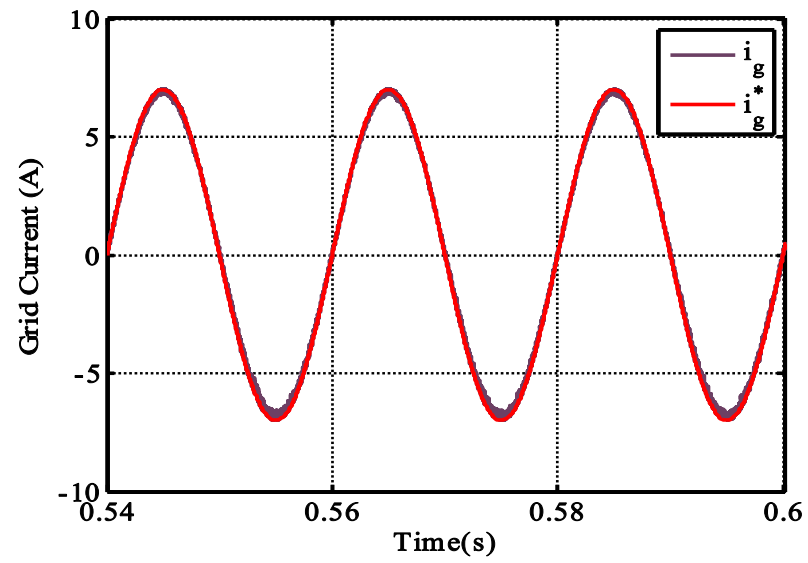

Fig. 7. Injected grid current

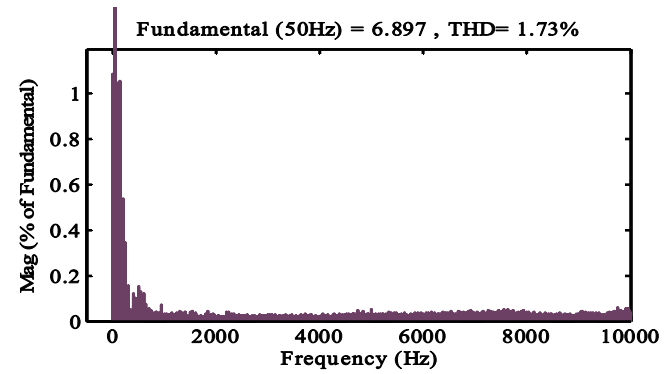

Fig. 8. qZS-CHB output current THD

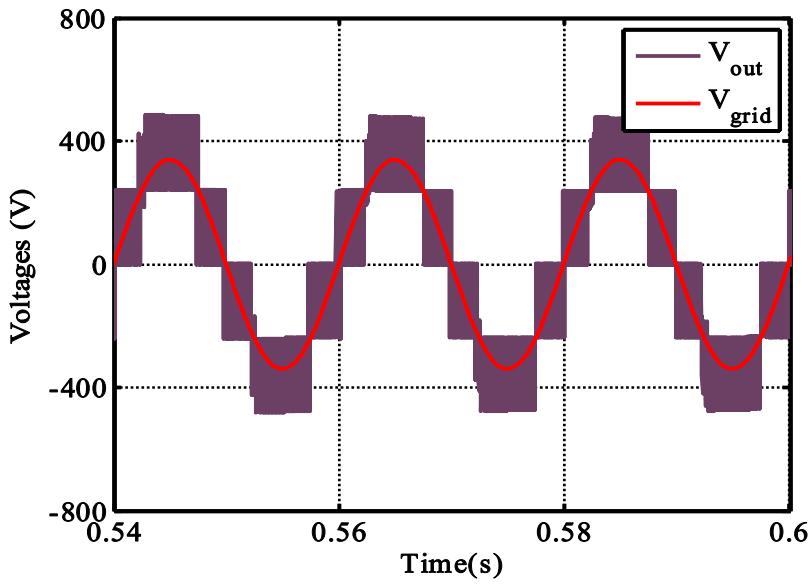

Fig. 9. qZS-CHB 5-level output voltages with the grid voltage
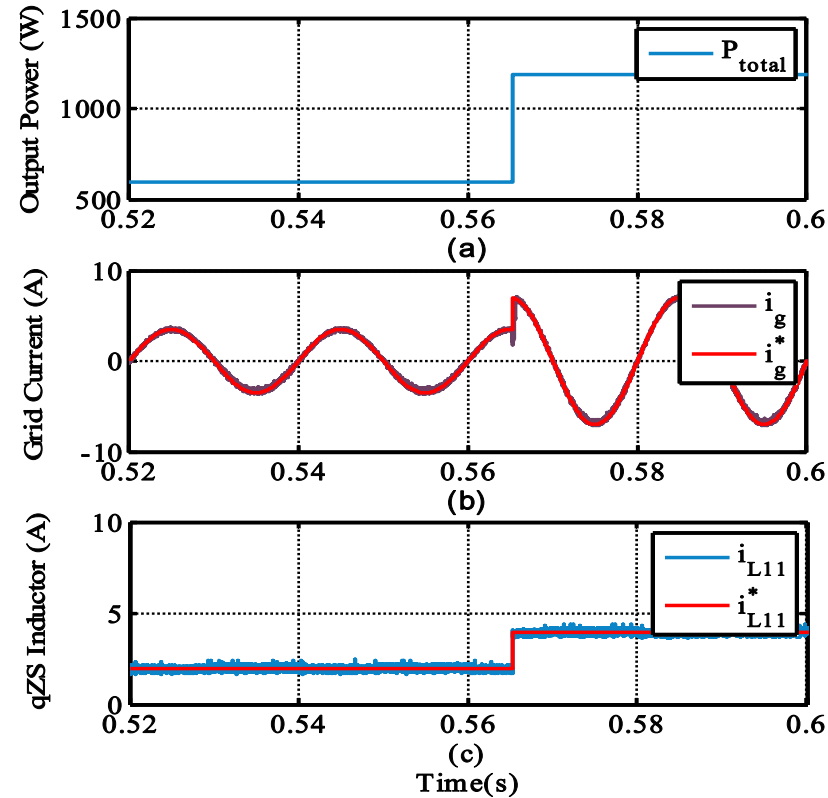

Fig. 10. Transient test, (a) Total output power, (b) qZS-CHB output current , (c) qZS inductor current

\section{CONCLUSIONS}

A finite control set MPC for grid-tie qZS based multilevel inverter has been proposed in this paper. The proposed system consists of a single-phase 2-cell CHB inverter where each module is fed by a qZS network The suggested multi-objective control strategy ensured the tracking of the grid current, qZS inductor currents and capacitor voltages with respect to their references, while balancing the DC-link voltage for both qZSCHB inverter modules. Grid-tie current injection with low THD and unity power factor has been achieved. The feasibility of this strategy has been validated in simulation using Matlab/Simulink environment.

\section{ACKNOWLEDGMENT}

This publication was made possible by the NPRP-EP award [X-033-2-007] from the Qatar National Research Fund (a member of Qatar Foundation). The statements made herein are solely the responsibility of the authors. 


\section{REFERENCES}

Abu-Rub, H.; Holtz, J.; Rodriguez, J.; Ge Baoming, "MediumVoltage Multilevel Converters-State of the Art, Challenges, and Requirements in Industrial Applications," Industrial Electronics, IEEE Transactions on , vol.57, no.8, pp.2581,2596, 2010. H. Abu-Rub, M. Malinowski, K. Al-Haddad, "Power Electronics for Renewable Energy Systems, Transportation and Industrial Applications", John Wiley \& Sons, 2014.

[3] J. Rodriguez, L. Jih-Sheng, and P. Fang Zheng, "Multilevel inverters: a survey of topologies, controls, and applications," Industrial Electronics, IEEE Transactions on, vol. 49, pp. 724-738, 2002.

C. Turpin, P. Baudesson, F. Richardeau, F. Forest, and T. A. Meynard, "Fault management of multicell converters," Industrial Electronics, IEEE Transactions on, vol. 49, pp. 988-997, 2002.

J. Rodriguez, P. W. Hammond, J. Pontt, R. Musalem, P. Lezana, and M. J. Escobar, "Operation of a Medium-Voltage Drive Under Faulty Conditions," Industrial Electronics, IEEE Transactions on, vol. 52, pp. 1080-1085, 2005.

Fathi, H.; Madadi, H., "Enhanced-Boost Z-Source Inverters With Switched Z-Impedance," in Industrial Electronics, IEEE Transactions on, vol.63, no.2, pp.691-703, Feb. 2016.

J. Anderson and F. Peng, "Four quasi-Z-Source inverters," in Power Electronics Specialists Conference, 2008. PESC 2008. IEEE, 2008, pp. 2743-2749.

M. Mosa, H. Abu-Rub, and J. Rodriguez, "High performance predictive control applied to three phase grid connected Quasi-ZSource Inverter," in Industrial Electronics Society, IECON 2013 39th Annual Conference of the IEEE, 2013, pp. 5812-5817.

O. Ellabban, M. Mosa, H. Abu-Rub, and J. Rodríguez, "Model Predictive Control of Grid Connected Quasi-Z-Source Inverter", IEEE International Conference on Industrial Technology, ICIT 2013, South Africa, 25 to 27 February 2013

Khajesalehi, J.; Sheshyekani, K.; Hamzeh, M.; Afjei, E., "Highperformance hybrid photovoltaic -battery system based on quasi-Zsource inverter: application in microgrids," in Generation, Transmission \& Distribution, IET, vol.9, no.10, pp.895-902, 72 2015.

Dongsen Sun; Baoming Ge; Weihua Liang; Abu-Rub, H.; Fang Zheng Peng, "An Energy Stored Quasi-Z-Source Cascade Multilevel Inverter-Based Photovoltaic Power Generation System," in Industrial Electronics, IEEE Transactions on, vol.62, no.9, pp.5458-5467, Sept. 2015.

Y. Liu, G. Baoming, H. Abu-Rub, and F. Z. Peng, "An Effective Control Method for Quasi-Z-Source Cascade Multilevel InverterBased Grid-Tie Single-Phase Photovoltaic Power System," Industrial Informatics, IEEE Transactions on, vol. 10, pp. 399-407, 2014.

[13] Yushan Liu, Baoming Ge, Haitham Abu-Rub, Fang Zheng Peng, An Effective Control Method for Three-Phase Quasi-Z-Source Cascade Multilevel Inverter based Grid-Tie Photovoltaic Power System, IEEE TRANSACTIONS ON INDUSTRIAL ELECTRONICS Volume: 61 Issue: 12 Pages: 6794-6802, 2014.

[14] Trabelsi, M.; Abu-Rub, H., "A unique active anti-islanding protection for a quasi-Z-Source based Power Conditioning System," IEEE Applied Power Electronics Conference and Exposition (APEC), 2015, pp. 2237-2243, 2015.

[15] J. Lee, "Model predictive control: Review of the three decades of development," International Journal of Control, Automation and Systems, vol. 9, pp. 415-424, 2011.

[16] J. Rodriguez, M. P. Kazmierkowski, J. R. Espinoza, P. Zanchetta, H. Abu-Rub, H. A. Young, et al., "State of the Art of Finite Control Set Model Predictive Control in Power Electronics," Industrial Informatics, IEEE Transactions on, vol. 9, pp. 1003-1016, 2013.

[17] J. Guzinski and H. Abu-Rub, "Speed Sensorless Induction Motor Drive With Predictive Current Controller," Industrial Electronics, IEEE Transactions on, vol. 60, pp. 699-709, 2013.
[18] J. Rodriguez and P. Cortes, Predictive Control of Power Converters and Electrical Drives: Wiley, 2012.

[19] J. Rodríguez, M. A. Pérez, H. Young, and H. Abu-Rub, "Model Predictive Speed Control of Electrical Machines," in Power Electronics for Renewable Energy Systems, Transportation and Industrial Applications, ed: John Wiley \& Sons, Ltd, 2014.

[20] J. Rodriguez, H. Abu-Rub, M. A. Perez, and S. Kouro, "Application of Predictive Control in Power Electronics: An AC-DC-AC Converter System," in Advanced and Intelligent Control in Power Electronics and Drives, ed: Springer, 2014.

[21] M. Rivera, J. Rodriguez, J. R. Espinoza, and H. Abu-Rub, "Instantaneous Reactive Power Minimization and Current Control for an Indirect Matrix Converter Under a Distorted AC Supply," Industrial Informatics, IEEE Transactions on, vol. 8, pp. 482-490, 2012.

[22] R. Vargas, J. Rodriguez, C. A. Rojas, and M. Rivera, "Predictive Control of an Induction Machine Fed by a Matrix Converter With Increased Efficiency and Reduced Common-Mode Voltage," Energy Conversion, IEEE Transactions on, vol. 29, pp. 473-485, 2014.

[23] W. Fengxiang, C. Zhe, P. Stolze, J. F. Stumper, J. Rodriguez, and R. Kennel, "Encoderless Finite-State Predictive Torque Control for Induction Machine With a Compensated MRAS," Industrial Informatics, IEEE Transactions on, vol. 10, pp. 1097-1106, 2014.

[24] A. Sanchez, A. De Castro, and J. Garrido, "A Comparison of Simulation and Hardware-in-the- Loop Alternatives for Digital Control of Power Converters," Industrial Informatics, IEEE Transactions on, vol. 8, pp. 491-500, 2012.

[25] M. P. Kazmierkowski, M. Jasinski, and G. Wrona, "DSP-Based Control of Grid-Connected Power Converters Operating Under Grid Distortions," Industrial Informatics, IEEE Transactions on, vol. 7, pp. 204-211, 2011.

[26] M. Trabelsi, K. A. Ghazi, N. Al-Emadi, and L. Ben-Brahim, "A weighted real-time predictive controller for a grid connected flying capacitors inverter," International Journal of Electrical Power \& Energy Systems, vol. 49, pp. 322-332, 2013.

[27] M. Trabelsi, L. Ben-Brahim, and K. A. Ghazi, "An improved RealTime Digital Feedback Control for grid-tie multilevel inverter," in Industrial Electronics Society, IECON 2013 - 39th Annual Conference of the IEEE, 2013, pp. 5776-5781.

[28] M. Trabelsi, K. A. Ghazi, N. Al-Emadi, and L. Ben-Brahim, "An original controller design for a grid connected PV system," in IECON 2012 - 38th Annual Conference on IEEE Industrial Electronics Society, 2012, pp. 924-929.

[29] Tarisciotti, L. ; Zanchetta, P. ; Watson, A. ; Bifaretti, S. ; Clare, J.C. ; Wheeler, P.W.; "Active DC Voltage Balancing PWM Technique for High-Power Cascaded Multilevel Converters", IEEE Transactions on Industrial Electronics, Volume: 61, Issue: 11 Publication Year: 2014, Page(s): 6157 - 6167.

[30] Tarisciotti, L. ; Zanchetta, P. ; Watson, A. ; Bifaretti, S. ; Clare, J.C. "Modulated Model Predictive Control for a Seven-Level Cascaded H-Bridge Back-to-Back Converter", IEEE Transactions on Industrial Electronics, Volume: 61 , Issue: 10, Publication Year: 2014 , Page(s): 5375 - 5383.

[31] S. Bifaretti, P. Zanchetta, L. Tarisciotti, A. Watson, J. Clare: "Advanced Power Electronic Conversion and Control System for Universal and Flexible Power Management", IEEE Transactions on Smart Grids, Volume: 2, Issue: 2, 2011, Page(s): 231 - 243.

[32] P. Cortes, M. P. Kazmierkowski, R. M. Kennel, D. E. Quevedo, and J. Rodriguez, "Predictive Control in Power Electronics and Drives," Industrial Electronics, IEEE Transactions on, vol. 55, pp. 43124324, 2008.

[33] S. Kouro, P. Cortes, R. Vargas, U. Ammann, and J. Rodriguez, "Model Predictive Control; A Simple and Powerful Method to Control Power Converters," Industrial Electronics, IEEE Transactions on, vol. 56, pp. 1826-1838, 2009. 